\title{
PHYSICS AT ENEM AND IN THE TECHNICAL CHEMISTRY COURSE AT THE INSTITUTO FEDERAL DO AMAPÁ (IFAP): A CURRICULAR COMPARISON
}

\section{ORIGINAL ARTICLE}

CARMO, Denny Rodrigues do ${ }^{1}$, BASTOS, Argemiro Midonês ${ }^{2}$, FECURY, Amanda Alves $^{3}$, DENDASCK, Carla Viana ${ }^{4}$, OLIVEIRA, Euzébio de ${ }^{5}$, DIAS, Claudio Alberto Gellis de Mattos 6

CARMO, Denny Rodrigues do. Et al. Physics at ENEM and in the technical chemistry course at the Instituto Federal Do Amapá (IFAP): A curricular comparison. Revista Científica Multidisciplinar Núcleo do Conhecimento. Year 06, Ed. 03, Vol. 03, pp. 80-88. March 2021. ISSN: 2448-0959, Access link: https://www.nucleodoconhecimento.com.br/education/physics-at-enem, DOI: 10.32749/nucleodoconhecimento.com.br/education/physics-at-enem

\section{ABSTRACT}

The National High School Examination (ENEM) is an evaluative and selective tool for students to enter higher education. The Federal Institutes of Education, Science and

\footnotetext{
${ }^{1}$ Student of the Technical Chemistry Course (high school) at the Institute of Basic, Technical and Technological Education of Amapá (IFAP).

${ }^{2}$ Physicist, PhD in Biodiversity and Biotechnology (UFPA), Professor and researcher of the Physics Degree Course at the Basic, Technical and Technological Institute of Amapá (IFAP) and the Graduate Program in Professional and Technological Education (PROFEPT IFAP).

${ }^{3}$ Biomedical, PhD in Topical Diseases, Professor and researcher of the Medicine Course at Campus Macapá, Federal University of Amapá (UNIFAP).

${ }^{4}$ Theologian, PhD in Clinical Psychoanalysis. She has worked for 15 years with Scientific Methodology (Research Method) in the Orientation of Scientific Production of Master's and PhD students. Specialist in Market Research and Research focused on the Health area.

${ }^{5}$ Biologist, PhD in Topical Diseases, Professor and researcher of the Physical Education Course at, Federal University of Pará (UFPA).

${ }^{6}$ Biologist, PhD in Behavior Theory and Research, Professor and researcher of the Chemistry Degree Course at the Institute of Basic, Technical and Technological Education of Amapá (IFAP) and the Graduate Program in Professional and Technological Education (PROFEPT IFAP).
}

RC: 78600

Disponível em: https://www.nucleodoconhecimento.com.br/education/physics-at- 
Technology (FIs) are institutions created by the Federal government with the objective of training competent professionals. The purpose of this study is to compare the content of the Physics questions of the National High School Examination (ENEM) between the years 2014 to 2018 with the curriculum content of the technical chemistry course at the Federal Institute of Amapá (IFAP). The teaching of physics in the technical course in Chemistry at IFAP does not present a division that prioritizes the subjects most present in ENEM. ENEM usually contextualizes its questions. This could be a common practice in high school physics, as it would help in your better understanding. In addition, it is necessary not to fragment the content during teaching, nor as its composition with other subjects. The IFAP technical course would not be the appropriate place of study for those who just want to finish high school. The content goes beyond what is required, but with cutouts focused on the technical part, including laboratory practices and strictly technical disciplines. The absence of interdisciplinarity and contextualization makes it difficult to absorb the content, forming students with difficulty in thinking about physics.

Keywords: ENEM, EPT, Teaching, Physics, IFAP.

\section{INTRODUCTION}

Created by the Federal Government of Brazil in 1998, the National High School Exam (ENEM) aimed to evaluate students who completed high school. Over time, ENEM has gained more relevance by being used not only as an assessment tool, but also as a selective tool for the entry of students into higher education (Silveira et al., 2015).

In the ENEM test, the subject of physics is approached along with the subjects of biology and chemistry in the area of Science of Nature knowledge. Even though there is no formal separation, it is possible to see that the questions of Natural Sciences can be organized between the three disciplines by analyzing the contents covered. (Silveira et al., 2015).

$\mathrm{RC}: 78600$

Disponível em: https://www.nucleodoconhecimento.com.br/education/physics-at- 
The Federal Institutes of Education, Science and Technology are institutions created by the Federal government with the objective of training competent professionals. These may present different courses such as undergraduate degrees, masters or doctorates, but the main modality is technical education, mainly technical education integrated with high school (Pacheco, 2010).

In Brazil, all states have at least one Federal Institute, some have even more than one, totaling 38 units. A Federal Institute can be divided into campuses, with a current total of 644 in operation. (Brasil, 2018).

The Federal Institute of Education, Science and Technology of the State of Amapá (IFAP) was created on December 28, 2008 with Law No. 11,892 (Marques et al., 2020) and aims to contribute to the development of the state (Castro et al., 2020). IFAP offers courses ranging from higher education to high school, and with that, it manages to reach a wide audience at different levels, it also consists of several campuses, of which we can mention the Macapá campus, located in the capital (Brasil, 2019; Penha et al., 2020).

The Macapá campus offers the high-level Chemistry Technical course in an integrated way. In this course we have the curricular components of the National Common Base referring to the areas of languages, mathematics, human sciences and natural sciences. Within the area of natural sciences, we have the curricular component of physics that is covered during the three years of the course. Each year has a workload of 80 hours per year and the contents taught are organized into four units, totaling 12 units over the three years. (Brasil, 2016).

At the Federal Institute of Amapá (IFAP) the subjects of the menu of the "Physics" component of the first year of the integral integrated technical course are: Introduction to Physics and Kinematics; Dynamics; Work and Energy (which also includes Amount of movement and Impulse); Gravitation and Fluid Statics. In the second year, the curriculum includes: Heat and Temperature; Thermodynamics;

RC: 78600

Disponível em: https://www.nucleodoconhecimento.com.br/education/physics-at- 
Geometric Optics; Oscillations and Waves (which also includes Simple Harmonic Movement). In the third and final year the contents are: Electrostatic; Electrodynamics; Magnetism; and Electromagnetism (Brasil, 2016).

Within the Enem curriculum matrix, there are competencies and knowledge objects related to these competencies. Knowledge objects related to physics are collected within 7 topics: Basic and fundamental knowledge (which includes subjects of Dimensional Analysis and Unit Systems); movement, balance and the discovery of physical laws (which includes, Kinematics, Dynamics, Hydrostatics, Static, Impulse and Amount of Movement); energy, work and power (which includes matters related to Work and Energy); the mechanics and functioning of the universe (which includes subjects related to Gravitation); electrical and magnetic phenomena (with subjects related to Electricity and Magnetism); oscillations, waves, optics and radiation (which includes subjects from Optics to Wave); and heat and thermal phenomena (which includes subjects related to thermology) (Brasil, 2015).

\section{GOALS}

Compare the content of the Physics questions of the National High School Examination (ENEM) between the years 2014 to 2018 with the curriculum content of the technical chemistry course at the Federal Institute of Amapá (IFAP).

\section{MATERIAL AND METHODS}

The research was carried out using questions from the National High School Exam (ENEM) taken from the Super Professor program (software), acquired from Interbits Informática (https://www.sprweb.com.br/mod_superpro/index.php). The physical discipline and the years 2014 to 2018 were selected in the program. The questions were classified according to the program (after analysis and removal of overlapping questions). Subsequently, a comparison was made between these and the syllabus of the physical component of the technical course of the Federal Institute of Amapá

RC: 78600

Disponível em: https://www.nucleodoconhecimento.com.br/education/physics-at- 
(IFAP). The bibliographic research was carried out on scientific articles, on computers of the Institute at the Federal Institute of Education, Science and Technology of Amapá, Campus Macapá, located at Rodovia BR 210 KM 3, s / n Bairro Brasil Novo. CEP: 68.909-398, Macapá, Amapá, Brazil. The data was compiled in the Excel application, part of the Microsoft Corporation's Office suite.

\section{RESULTS}

The classification of the overlapping content of ENEM physics questions between 2014 and 2018, by quantity and percentage of questions appears in table 1 . Three (3) subjects do not present any question (Dimensional analysis / system of units, gravitation and modern physics). Most subjects have one (1) or two (2) questions. Electricity + Magnetism and Kinematics present 4 questions each. Six (6) of the questions are for the subject of Work and Energy as well as for the subject of Optics. The Wave subject comprises a total of 17 questions.

RC: 78600

Disponível em: https://www.nucleodoconhecimento.com.br/education/physics-at- 
Table 1 Classification of the overlapping content of ENEM physics questions between 2014 and 2018, by quantity and percentage of questions.

\begin{tabular}{l|c|c}
\hline \multicolumn{3}{c}{ Classificação do autor após análise de conteúdo sobreposto } \\
\hline Análise Dimensional / Sistemas de Unidades & Quantidade & Porcentagem \\
\hline Gravitação & 0 & $0 \%$ \\
\hline Moderna & 0 & $0 \%$ \\
\hline Cinemática + Impulso e Quantidade de Movimento & 0 & $0 \%$ \\
\hline Dinâmica + Impulso e Quantidade de Movimento & 1 & $2 \%$ \\
\hline Hidrodinâmica & 1 & $2 \%$ \\
\hline Hidrostática & 1 & $2 \%$ \\
\hline Trabalho e Energia + Movimento Harmônico & 1 & $2 \%$ \\
\hline Temática + Trabalho e energia & 1 & $2 \%$ \\
\hline Tematica & 1 & $2 \%$ \\
\hline Cinemática + Dinâmica & 2 & $3 \%$ \\
\hline Dinâmica & 2 & $3 \%$ \\
\hline Estática & 2 & $3 \%$ \\
\hline Impulso e Quantidade de Movimento & 2 & $3 \%$ \\
\hline Trabalho e Energia + termologia & 2 & $3 \%$ \\
\hline Eletricidade + Magnetismo & 4 & $7 \%$ \\
\hline Cinemática & 4 & $7 \%$ \\
\hline Trabalho e Energia & 6 & $10 \%$ \\
\hline Óptica & 6 & $10 \%$ \\
\hline Termologia & 7 & $11 \%$ \\
\hline Ondulatória & $\mathbf{2 1}$ & $\mathbf{2 8} \%$ \\
\hline
\end{tabular}

Table 2 shows the subjects of the physics menu of the technical course in chemistry at IFAP, showing the unit number (per bimonth) and the year that are covered. Units I to IV must be taught in eighty (80) class hours. In the first year, 12 hours are normally used to teach unit I, 28 hours to teach unit II, 20 hours for unit III, and 20 hours for unit IV. In the second year, unit I is usually taught in 20 hours, as well as each of the later units (II, III and IV). In the third year, unit I is completed in 16 hours, unit II in 36 hours, unit III in 14 hours, and unit IV in 14 hours.

RC: 78600

Disponível em: https://www.nucleodoconhecimento.com.br/education/physics-at- 
Table 2. Subjects of the physics menu of the technical course in chemistry at IFAP, by year and unit.

\begin{tabular}{|c|c|c|c|c|c|c|}
\hline \multirow[b]{2}{*}{ Unidade } & \multicolumn{6}{|c|}{ Ano } \\
\hline & $1^{\circ}$ Ano & $\begin{array}{c}\mathrm{n}^{\circ} \text { de horas } \\
\text { aulas }\end{array}$ & $2^{\circ}$ Ano & $\begin{array}{c}\mathrm{n}^{\circ} \text { de horas } \\
\text { aulas }\end{array}$ & $3^{\circ}$ Ano & $\begin{array}{c}\mathrm{n}^{\circ} \text { de horas } \\
\text { aulas }\end{array}$ \\
\hline I & $\begin{array}{l}\text { Introdução à } \\
\text { Fisica e } \\
\text { Cinemática } \\
\end{array}$ & 12 & $\begin{array}{c}\text { Calore } \\
\text { Temperatura }\end{array}$ & 20 & Eletrostática & 16 \\
\hline II & $\begin{array}{c}\text { Dinâmica } \\
\text { (evidenciando o } \\
\text { conceito de força } \\
\text { e aplicações) }\end{array}$ & 28 & Termodinâmica & 20 & Eletrođinâmica & 36 \\
\hline III & $\begin{array}{c}\text { Trabalho e } \\
\text { Energia }\end{array}$ & 20 & $\begin{array}{c}\text { Óptica } \\
\text { Geométrica }\end{array}$ & 20 & Magnetismo & 14 \\
\hline IV & $\begin{array}{c}\text { Gravitação e } \\
\text { Estática dos } \\
\text { Fluidos }\end{array}$ & 20 & $\begin{array}{l}\text { Oscilações e } \\
\text { Ondas }\end{array}$ & 20 & Eletromagnetismo & 14 \\
\hline $\begin{array}{l}\text { no aulas da } \\
\text { matriz anual }\end{array}$ & & 80 & & 80 & & 80 \\
\hline
\end{tabular}

The simplified classification of the content of ENEM physics questions between 2014 and 2018 , by quantity and percentage of questions, is shown in table 3 . The Thematic subject appears in $2 \%$ of the questions, followed by the subject Electricity + Magnestimo (7\%), optics (10\%), Thermology (11\%); Wave (28\%), and Mechanical $(43 \%)$.

RC: 78600

Disponível em: https://www.nucleodoconhecimento.com.br/education/physics-at- 
Table 3. Simplified classification of the content of ENEM physics questions between 2014 and 2018, by quantity and percentage of questions.

\begin{tabular}{l|c|c|}
\hline Assunto & Quantidade & Porcentagem \\
\hline Tematica & 1 & $2 \%$ \\
\hline Eletricidade + Magnetismo & 4 & $7 \%$ \\
\hline Óptica & 6 & $10 \%$ \\
\hline Termologia & 7 & $11 \%$ \\
\hline Ondulatória & 17 & $28 \%$ \\
\hline Mecânica & 26 & $43 \%$ \\
\hline Total & $\mathbf{6 1}$ & $\mathbf{1 0 0} \%$ \\
\hline
\end{tabular}

The simplified classification of the content of ENEM physics questions between 2014 and 2018, divided by the year in which they are taught in the technical course in chemistry at IFAP are shown in table 4 . The percentage being shown refers to the portion of ENEM questions within each Subject.

Table 4. Simplified classification of the content of ENEM physics questions between 2014 and 2018, divided by the year in which they are taught in the technical course in chemistry at IFAP

\begin{tabular}{|c|c|c|c|c|}
\hline & \multicolumn{4}{|c|}{ Curso técnico em química do IFAP } \\
\hline & $1^{\circ}$ & $2^{\circ}$ & $3^{a}$ & Todos \\
\hline \multirow{3}{*}{$\begin{array}{c}\text { Assuntos com } \\
\text { as porcentagem } \\
\text { de questões }\end{array}$} & \multirow{3}{*}{ Mecânica (43\%) } & Óptica $(10 \%)$ & \multirow{3}{*}{$\begin{array}{c}\text { Eletricidade + } \\
\text { Magnestismo (7\%) }\end{array}$} & \multirow{3}{*}{ Tematica $(2 \%)$} \\
\hline & & Termologia (11\%) & & \\
\hline & & Ondulatória (28\%) & & \\
\hline $\begin{array}{l}\text { Porcentagem } \\
\text { Total } \\
\end{array}$ & $43 \%$ & $49 \%$ & $7 \%$ & $100 \%$ \\
\hline
\end{tabular}

RC: 78600

Disponível em: https://www.nucleodoconhecimento.com.br/education/physics-at- 
Figure 1 shows the number of physics questions at ENEM between 2014 and 2018 according to the degree of difficulty. The questions classified by the Super professor program as having low difficulty decreased in quantity from 2014 to 2016 , increasing again from 2016 to 2018. Those of medium difficulty increased from 2014 to 2016 , and decreased from 2016 to 2018 . Those considered to be of high difficulty appear only in 2015.

Figure 1 Number of physics questions at ENEM between 2014 and 2018 according to the degree of difficulty

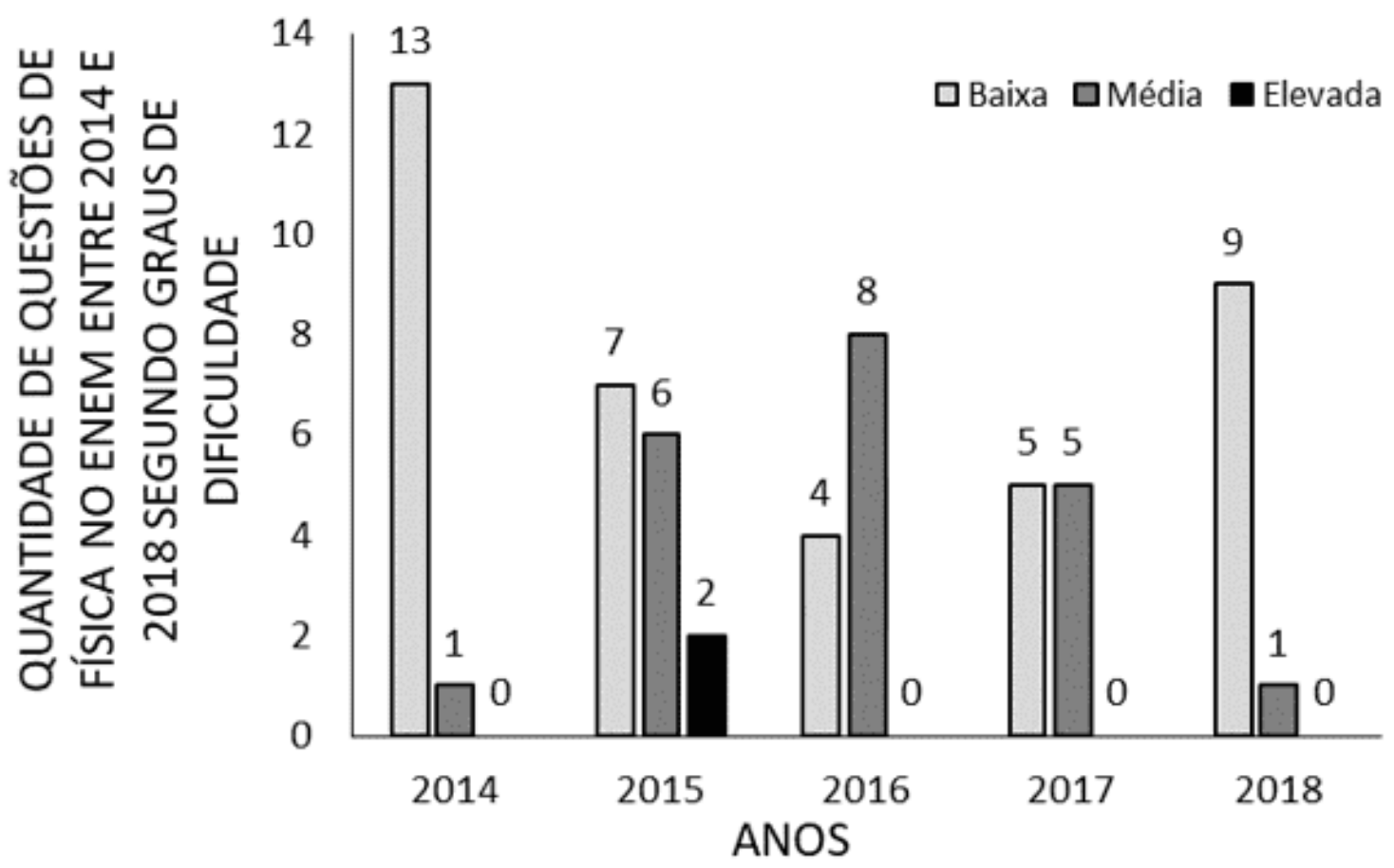

\section{DISCUSSION}

The National High School Exam has as a parameter to contextualize the questions of the physical exam linking them to people's daily lives (Silveira et al., 2014). In this sense, the difference presented between the subjects of the physics assessment in

RC: 78600

Disponível em: https://www.nucleodoconhecimento.com.br/education/physics-at- 
the studied period (table 1) may have occurred as a consequence of this contextualization. In a study on the presence of physics in the daily lives of working students, questions were found about the use of different energies (electrical, chemical), in situations such as alcohol production plants and locations for the installation of sound equipment in automobiles (Toti and Pierson , 2010). Optics also appears routinely in people's lives. The study of light can help an engineer to know how much shade his projected building will cause in the neighborhood; or like a cup or a metallic object, you read an image; or even because the sky is blue when the day is sunny (Ribeiro and Verdeaux, 2012).

In the technical course, as part of electromagnetism, there is an introduction to special relativity, which is a subject of modern physics (Brasil, 2016). Modern physics in high school is not yet a consolidated content and there is no consensus on its teaching. Probably for this reason the absence of this topic in ENEM (Silva et al., 2013).

Usually, curricula divide the school year of high school into four bimonths. Each twomonth period corresponds to a unit, with 20 hours each. In a year with 80 hours, the division would then be equitable. However, some subjects take longer than others to be taught (table 2). The difference between the planned time and the real time for each unit is probably due to the fragmented programming of the content. In this way, learning becomes unchained, and the content presented, fragmented, has different difficulty factors, requiring less or more hours for its completion (Gaspar, 1997). In addition, class time in a traditional classroom is also spent on other tasks (call, notes) and not on teaching the discipline itself (Pires and Veit, 2006).

In the reference matrix of Enem, most of the objects of study are related to mechanics. In this same matrix, the subjects of wave, optics, electromagnetism and thermodynamics have a similar number of objects. But, the presence of these subjects in the questions is not similar. Only mechanics is very present both in this matrix and in the questions (table 3). The reference matrix encompasses, in the

$\mathrm{RC}: 78600$

Disponível em: https://www.nucleodoconhecimento.com.br/education/physics-at- 
mechanics topic, many different concepts, which does not occur with other subjects, for example, wave. Perhaps this division practiced by ENEM and different from the division of technical high school, causes the observed percentage difference (Brasil, 2015)

Some content taught in the physical component within the technical course of chemistry at IFAP has, for example, a charge of 80 hours (electricity + magnetism) and corresponds to $7 \%$ of the content charged in ENEM. Others, such as thermology, are taught in technical education in 40 hours and correspond to $11 \%$ of the national exam. Still others, as a wave, represent $28 \%$ of the ENEM assessment and are taught in 20 hours. This disparity probably occurs because the fundamental role of IFAP, in the aforementioned course, is to train technicians in chemistry (Brasil, 2019). This does not mean that students who complete technical secondary education do not take ENEM to enter higher education.

The teaching of physics still presents difficulties regarding the absorption of knowledge by the students, which means that most students do not present satisfactory performance in this discipline (Sbf, 2011; Barroso et al., 2018).

The ENEM test should be consistent with what the student learned in high school (normal or technical). It was possible to see that the difficulty of ENEM has changed over the years (figure 1). The attempt to increase the difficulty of the national exam questions (2014 to 2016) was reversed in the following two years. Probably as the teaching of physics at the secondary level still has a low performance of knowledge absorption, perhaps this has influenced the decision to lower the level of difficulty of this component in the 2017 and 2018 exams (Barroso et al., 2018).

\section{CONCLUSION}

The teaching of physics in the technical course in Chemistry at IFAP does not present a division that prioritizes the subjects most present in ENEM.

$\mathrm{RC}: 78600$

Disponível em: https://www.nucleodoconhecimento.com.br/education/physics-at- 
ENEM usually contextualizes its questions. This could be a common practice in high school physics, as it would help in your better understanding. In addition, it is necessary not to fragment the content during teaching, nor as its composition with other subjects.

The technical course at IFAP would not be the appropriate place of study for those who just want to finish high school. The content goes beyond what is required, but with cutouts geared to the technical part, including laboratory practices and strictly technical disciplines.

The absence of interdisciplinarity and contextualization makes it difficult to absorb the content, forming students with difficulty in thinking about physics.

\section{REFERENCES}

BARROSO, M. F.; RUBINI, G.; SILVA, T. Dificuldades na aprendizagem de Física sob a ótica dos resultados do Enem. Rev. Bras. Ensino Fís., v. 40, n. 4, p. e4402, 2018.

BRASIL. Matriz de Referência Enem. Brasilia DF, 2015. Disponível em: < http://download.inep.gov.br/download/enem/matriz_referencia.pdf >. Acesso em: 25 mar 2020.

. Curso Técnico de Nível Médio em Química na Forma Integrada Regime Integral: Plano de Curso. Macapá AP, 2016. Disponível em: < https://portal.ifap.edu.br/index.php/publicacoes/item/1100-resolucao-n-20-2018consup >. Acesso em: 27 abril 2019.

. Expansão da Rede Federal. Rede Federal de Educação Profissional, Científica e Tecnológica. 2018. Disponível em: < http://redefederal.mec.gov.br/expansao-da-rede-federal >. Acesso em: 27 abril 2019.

RC: 78600

Disponível em: https://www.nucleodoconhecimento.com.br/education/physics-at- 
. Curso Técnico em Química - Integrado - Campus Macapá. Macapá AP, 2019.

http://www.ifap.edu.br/index.php/component/content/article?id=398 >. Acesso em: 27 abril 2019.

CASTRO, G. N. V. et al. Análise de Eficiência Acadêmica dos cursos subsequentes, nas modalidades à distância e presencial, ofertados pelo Instituto Federal do Amapá (2018). Research, Society and Development, v. 9, n. 8, p. e208985262, 2020. https://rsdjournal.org/index.php/rsd/article/view/5262

GASPAR, A. Cinqüenta anos de ensino de Física: Muitos equívocos, alguns acertos e a necessidade do resgate do papel do professor $\underline{X V \text { Encontro de }}$ Físicos do norte e Nordeste Natal RN 1997.

MARQUES, J. D. C. et al. Nível Médio Técnico e Cursos de Graduação: comparativo de vagas e ingressantes no Instituto Federal do Amapá, Brasil (20172018). Research, Society and Development, v. 9, n. 8, p. e228985375, 2020 https://rsdjournal.org/index.php/rsd/article/view/5375

PACHECO, E. M. Os Institutos Federais: Uma Revolução na Educação Profissional e Tecnológica. Natal RN: IFRN, 2010. 28p.

PENHA, A. C. F. M. et al. Matrículas da Educação Especial na Educação Profissional Técnica de Nível Médio no Estado do Amapá (2015-2018). Research, $\begin{array}{lllllll}\text { Society and Development, v. } & 9, & \text { n. } & \text { 7, } & \text { p. } & \text { e881974867, }\end{array}$ https://rsdjournal.org/index.php/rsd/article/view/4867

PIRES, M. A.; VEIT, E. A. Tecnologias de Informação e Comunicação para ampliar e motivar o aprendizado de Fısica no Ensino Medio. Revista Brasileira de Ensino de Fisica, v. 28, n. 2, p. $241-248,2006$.

RC: 78600

Disponível em: https://www.nucleodoconhecimento.com.br/education/physics-at- 
RIBEIRO, J. L. P.; VERDEAUX, M. D. F. D. S. Atividades experimentais no ensino de óptica: uma revisão. Revista Brasileira de Ensino de Fısica, v. 34, n. 4, p. 110, 2012.

SBF. Carta aberta ao Inep quanto à adoção do Exame Nacional do Ensino Médio como critério de ingresso nas Universidades. São Paulo SP, 2011. Disponível em: < http://www.sbfisica.org.br/v1/arquivos_diversos/noticias/maio2014/carta-aoINEP.pdf >. Acesso em: 05 fev 2021.

SILVA, J. R. N. D.; ARENGHI, L. E. B.; LINO, A. Porque inserir física moderna e contemporânea no ensino médio? Uma revisão das justificativas dos trabalhos acadêmicos. R. B. E. C. T., v. 6, n. 1, p. 1-15, 2013.

SILVEIRA, F. L.; BARBOSA, M. C. B.; SILVA, R. Exame Nacional do Ensino Médio (ENEM): Uma análise crítica Rev. Bras. Ensino Fís., v. 37, n. 1, p. 1101, 2015.

SILVEIRA, F. L.; STILCK, J.; BARBOSA, M. Comunicações: Manifesto sobre a qualidade das questões de Física na Prova de Ciências da natureza no Exame Nacional de Ensino Médio. Caderno Brasileiro de Ensino de Física, v. 31, n. 2, p. 473-479, 2014.

TOTI, F. A.; PIERSON, A. H. C. Elementos para uma aproximação entre a física no ensino médio e o cotidiano de trabalho de estudantes trabalhadores. Investigações em Ensino de Ciência, v. 15, n. 3, p. 527-552, 2010

Posted: March, 2021

Approved: March, 2021

RC: 78600

Disponível em: https://www.nucleodoconhecimento.com.br/education/physics-at- 